\title{
CONVERGENCE/DIVERGENCE ANALYSIS AND DIFFERENTIATION IN MACROECONOMIC VARIABLES IN THE DEVELOPMENT OF THE RUSSIAN FEDERATION
}

\author{
Aleksy Kornowski \\ Faculty of Management and Social Communication, Jagiellonian University in Krakow, \\ Krakow, Poland \\ alex.kornowski@gmail.com
}

\begin{abstract}
The purpose of this paper is to analyze the economic development and the diversification of the individual regions of the Russian Federation (RF) on the basis of taxonomic indices and a convergence/divergence analysis of five macroeconomic variables, namely registered unemployment rate, investment per capita, gross domestic product $(G D P)$ per capita, wages, and the number of organizations conducting research and development (R\&D) per million inhabitants, for the period between 2000 and 2012 (the period was chosen due to lack of data for years 2014, 2015 and 2016 for few regions). The study covers 79 regions, and the data used for the analyses comes from the Russian Statistical. The principal method of analysis is the taxonomic index based on Euclidean metrics. The spatial differentiation in the development of RF regions demonstrates the specific character of the individual regions of Russia. The analysis made leads to the conclusion that the most developed regions in terms of the analyzed variables are of industrial and mining character, while the least developed ones are agricultural in character. The structure of this paper is as follows: the spatial differentiation of macroeconomic variables in $R F$ regions, registered unemployment rate, per capita investment, per capita GDP, wages, and number of organizations conducting $R \& D$ activities per million inhabitants is discussed in section 2; the definition of a taxonomic index based on Euclidean metrics is presented in section 3; the analysis of the diversified development of $R F$ regions based on taxonomic indicators is given in section 4, a preliminary convergence/divergence analysis is presented in section 5, while section 6 provides a key conclusions.
\end{abstract}

Keywords: Russian Federation, economic development, regional economic development, differentiation of macroeconomic variables.

JEL classification: 011.

\section{Introduction}

When analyzing the development of the Russian economy, one should be aware of its developmental specificities in the individual parts of the country. In terms of economic development, Russia can be divided into two parts: the European part and the Asian part. The European part is characterized by a larger number of inhabitants and a relatively underdeveloped mining industry. In contrast, the Asian part features a well-developed mining and processing industry, with a relatively small number of inhabitants (Russian Statistical Office, 2020). This paper begins with the discussion of the spatial differentiation of macroeconomic variables in RF regions, followed by a definition of the Euclidean metric-based taxonomic index applied in the study, an analysis of the diversity in regional development in the Russian Federation based on the taxonomic indices, and a comparison of the degree of spatial differentiation of the analysed variables. The paper closes with an initial analysis of the $\sigma$-convergence of these macroeconomic variables and conclusions that 
the most developed RF regions include good condition of the service sector and the development of industry branches specific and their immediate environment, such as mechanical engineering, food industry, oil and gas processing, research and development, pharmaceutical industry, metallurgy, chemical industry, and production of building materials.

\section{Literature review}

The experience of many countries shows that the processes of economic growth and development of economies are characterized by considerable imbalance both in time and in space. The results of empirical research suggest that the equalization of development levels occurs to a greater extent between regions of a given country and member countries of regional integration systems than on an international scale (Barro, Sala-i-Martin 2004: 410). However, under the influence of deepening economic globalization it is often difficult to find empirical evidence supporting the thesis, that reducing the disparities in regional development is characteristic of most national economies.

This problem also affects the economy of the Russian Federation. Historically determined, including experiences related to the period of central planning, mean that economic inequalities between regions are largely responsible for the current polarization of the country's economic development. The issue of differentiation of economic development and taxonomic indicator is discussed in Blackwelder (1966), Cole (1968), Taylor (1970), Sneath and Sokal (1973), Mezzich and Solomon (1980), Majewski (1999), Dykas (2010), Tokarski and Jabłoński (2010), Kornowski (2015),

The issue of convergence is one of the most developing areas of research within the framework of macroeconomic theory of economic growth, is discussed in Islam (2003), Gajewski and Tokarski (2004), Malaga and Kliber (2007), Misiak, Tokarski and Włodarczyk (2011).

\section{Spatial differentiation of selected macroeconomic variables in the regions of the Russian Federation}

\subsection{Registered unemployment rate}

Table 1 presents the differentiation of the unemployment rate in RF regions between 2000 and 2012, divided into quintile groups.

Table 1: Spatial differentiation of the unemployment rate (\%) registered in the regions of the Russian Federation in period between 2000 and 2012

\begin{tabular}{|c|c|}
\hline Group & $\begin{array}{c}\text { RF Region } \\
\text { (Unemployment Rate) }\end{array}$ \\
\hline $6.29^{1}$ & $\begin{array}{l}\text { Moscow (1.64); St. Petersburg (3); Moscow Oblast (3.97); Chukotka } \\
\text { Autonomous Region (5.1); Tula Oblast (5.15); Yaroslavl Oblast (5.24); Lipetsk } \\
\text { Oblast (5.25); Samara Oblast (5.37); Belgorod Oblast (5.6); Novgorod Oblast } \\
\text { (5.66); Kostroma Oblast (5.68); Kaluga Oblast (5.96); Tver Oblast (6.01); } \\
\text { Republic of Tatarstan (6.17); Chelyabinsk Oblast (6.2); Leningrad Oblast (6.28). }\end{array}$ \\
\hline 7.8 & $\begin{array}{l}\text { Republic of Mordovia (6.3); Vologda Oblast (6.42); Ivanovo Oblast (6.64); } \\
\text { Nizhny Novgorod Oblast (6.68); Ryazan Oblast (7.01); Oryol Oblast (7.04); } \\
\text { Magadan Oblast (7.2); Ulyanovsk Oblast (7.26); Sverdlovsk Oblast (7.28); } \\
\text { Arkhangelsk Oblast (7.32); Voronezh Oblast (7.47); Tyumen Oblast (7.53); } \\
\text { Kursk Oblast (7.55); Penza Oblast (7.61); Khabarovsk Krai (7.73); Krasnodar } \\
\text { Oblast (7.8). }\end{array}$ \\
\hline
\end{tabular}

\footnotetext{
${ }^{1}$ Upper limit of group.
} 


\begin{tabular}{|c|c|}
\hline 8.54 & $\begin{array}{l}\text { Kirov Oblast (7.82); Udmurt Republic (7.9); Republic of Bashkortostan (7.93); } \\
\text { Perm Oblast (7.94); Republic of Karelia (7.98); Pskov Oblast (8.07); Bryansk } \\
\text { Oblast (8.12); Krasnoyarsk Oblast (8.17); Kaliningrad Oblast (8.18); Saratov } \\
\text { Oblast (8.27); Volgograd Oblast (8.37); Vladimir Oblast (8.39); Orenburg Oblast } \\
\text { (8.48); Sakhalin Oblast (8.49); Stavropolsky Krai (8.49). }\end{array}$ \\
\hline 9.68 & $\begin{array}{l}\text { Smolensk Oblast (8.56); Kemerovo Oblast (8.64); Primorsky Krai (8.64); } \\
\text { Tambov Oblast (8.65); Amur Oblast (8.8); Republic of Khakassia (8.82); } \\
\text { Republic of Sakha (Yakutia) (8.84); Novosibirsk Oblast (9); Omsk Oblast (9.02); } \\
\text { Chuvash Republic (9.09); Murmansk Oblast (9.12); Altai Krai (9.2); Jewish } \\
\text { Autonomous Oblast (9.22); Rostov Oblast (9.23); Astrakhan Oblast (9.65); } \\
\text { Kamchatka Krai (9.67). }\end{array}$ \\
\hline 5 & $\begin{array}{l}\text { Tomsk Oblast (9.7); Irkutsk Oblast (9.85); Mari El Republic (10.19); Komi } \\
\text { Republic (10.48); Kurgan Oblast (11.07); Altai Republic (11.58); Zabaykalsky } \\
\text { Krai (11.64); Republic of North Ossetia - Alania (11.7); Republic of Adygea } \\
\text { (11.75); Republic of Buryatia (13.74); Karachay-Cherkess Republic (15.08); } \\
\text { Republic of Kalmykia (17); Kabardino-Balkaria (17.54); Republic of Dagestan } \\
\text { (19.85); Tyva Republic (20.35); Republic of Ingushetia (48.17). }\end{array}$ \\
\hline
\end{tabular}

Source: own summary based on the data from the Russian Statistical Office website.

Considering the data presented in Table 1, one observes that the spatial differentiation of the unemployment rate in RF regions from 2000 to 2012 is as follows:

The spatial diversification of the unemployment rate in RF regions from 2000 to 2012 (Table 1) is as follows:

1) The lowest unemployment rate, not exceeding $6.29 \%$;

Group (1) includes regions with a well-developed mining industry, a well-developed service sector and a B\&R sector;

2) Low unemployment, from $6.29 \%$ to $7.8 \%$;

3) Medium unemployment rate, from $7.9 \%$ to $8.54 \%$;

4) High unemployment rate, from $8.55 \%$ to $9.67 \%$;

5) The highest unemployment rate, above $9.68 \%$;

Group (5) includes regions with a relatively underdeveloped industrial and service sector. These are mostly agricultural regions characterized by a low level of GDP per capita (see Table 3).

\subsection{Investments per capita}

Table 2 presents the spatial differentiation of per capita investment from 2000 to 2012, divided into quintile groups.

Table 2: Spatial differentiation of per capita investments (USD) at constant prices from 2012 in the period between 2000 and 2012

\begin{tabular}{|c|c|}
\hline Group & $\begin{array}{c}\text { RF Region } \\
\text { (Per Capita Investment) }\end{array}$ \\
\hline $\begin{array}{l}1 \\
563.15\end{array}$ & $\begin{array}{l}\text { Republic of Ingushetia (284.02); Tyva Republic (313.6); Kabardino-Balkaria } \\
\text { (370.04); Republic of North Ossetia - Alania (402.09); Altai Krai (406.5); } \\
\text { Ivanovo Oblast (426.94); Bryansk Oblast (427.53); Karachay-Cherkess } \\
\text { Republic (448.18); Pskov Oblast (477.04); Kostroma Oblast (492.43); Kirov } \\
\text { Oblast (497.16); Republic of Adygea (516.86); Kurgan Oblast (518.35); Mari } \\
\text { El Republic (530.45); Stavropolsky Krai (532.18); Republic of Buryatia } \\
\text { (540.98). }\end{array}$ \\
\hline
\end{tabular}




\begin{tabular}{|c|c|}
\hline & $\begin{array}{l}\text { Vladimir Oblast (577.93); Saratov Oblast (579.72); Republic of Kalmykia } \\
\text { (586.52); Oryol Oblast (592.6); Republic of Dagestan (594.09); Volgograd } \\
\text { Oblast (596.42); Udmurt Republic (616.19); Penza Oblast (616.8); Ulyanovsk } \\
\text { Oblast (640.23); Chuvash Republic (655.4); Tula Oblast (667.12); Rostov } \\
\text { Oblast (684.47); Omsk Oblast (704.76); Altai Republic (713.03); Zabaykalsky } \\
\text { Krai (714.34); Kursk Oblast (715.83). }\end{array}$ \\
\hline 942.59 & $\begin{array}{l}\text { Ryazan Oblast (717.24); Smolensk Oblast (729.72); Republic of Karelia } \\
\text { (749.64); Novosibirsk Oblast (752.08); Republic of Khakassia (770.88); } \\
\text { Tambov Oblast (775.59); Republic of Mordovia (791.43); Voronezh Oblast } \\
\text { (804.1); Chelyabinsk Oblast (813.92); Republic of Bashkortostan (818.79); } \\
\text { Tver Oblast (860.38); Irkutsk Oblast (874.63); Samara Oblast (884.17); } \\
\text { Orenburg Oblast (896.14); Yaroslavl Oblast (900.85). }\end{array}$ \\
\hline 1390.46 & $\begin{array}{l}\text { Perm Oblast (953.03); Novgorod Oblast (954.77); Murmansk Oblast (966.41); } \\
\text { Nizhny Novgorod Oblast (990.02); Sverdlovsk Oblast (1019.45); Kaluga } \\
\text { Oblast (1022.35); Kemerovo Oblast (1046.8); Moscow Oblast (1089.84); } \\
\text { Belgorod Oblast (1116.7); Kaliningrad Oblast (1119.51); Astrakhan Oblast } \\
\text { (1120.21); Primorsky Krai (1217.2); Lipetsk Oblast (1270.77); Kamchatka Krai } \\
\text { (1290.78); St. Petersburg (1299.7); Vologda Oblast (1389.45). }\end{array}$ \\
\hline 5 & $\begin{array}{l}\text { Tomsk Oblast (1391.98); Jewish Autonomous Oblast (1406.53); Krasnoyarsk } \\
\text { Oblast (1421.41); Moscow (1422.47); Republic of Tatarstan (1484.79); } \\
\text { Khabarovsk Krai (1508.81); Krasnodar Oblast (1520.18); Amur Oblast } \\
\text { (1554.45); Magadan Oblast (1712.91); Arkhangelsk Oblast (1726.61); } \\
\text { Leningrad Oblast (2305.34); Komi Republic (2476.77); Republic of Sakha } \\
\text { (Yakutia) (2834.24); Chukotka Autonomous Region (3955.42); Sakhalin } \\
\text { Oblast (5519.24); Tyumen Oblast (5881.76). }\end{array}$ \\
\hline
\end{tabular}

Source: own summary based on the data from the Russian Statistical Office website.

The spatial diversification of per capita investment in RF regions from 2000 to 2012 (Table 2) is as follows:

1) The lowest value of per capita investment not exceeding 563.15 USD;

Group (1) includes the least attractive regions for investors owing to their underdeveloped industrial, mining or agricultural sectors;

2) Low level of per capita investment from 563.15 to 716.11 USD;

3) Medium level of per capita investment from 716.12 to 942.59 USD;

4) High level of per capita investment from 942.60 to 1390.46 USD;

5) The highest level of per capita investment above 1390.46 USD;

Group (5) includes the most attractive regions for investors owing to their mining and industrial sectors that are actively being developed in the regions.

\subsection{Gross domestic product per capita}

Table 3 illustrates the gross domestic product per capita from 2000 to 2012, divided into quintile groups.

Table 3: Spatial differentiation of per capita gross domestic product (USD) at constant prices from 2012 in the period between 2000 and 2012

\begin{tabular}{|c|c|}
\hline Group & $\begin{array}{c}\text { RF Region } \\
\text { (Per Capita GDP) }\end{array}$ \\
\hline 1 & 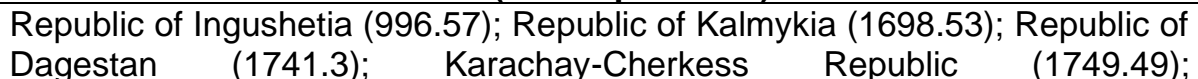 \\
\hline 2447.47 & $\begin{array}{l}\text { Kabardino-Balkaria (1755.78); Tyva Republic (1809.39); Ivanovo Oblast } \\
\text { (1902.33); Republic of Adygea (1925.48); Republic of North Ossetia - Alania } \\
\text { (1989.46); Altai Republic (2099.06); Bryansk Oblast (2241.83); Mari El }\end{array}$ \\
\hline
\end{tabular}




\begin{tabular}{|c|c|}
\hline & $\begin{array}{l}\text { Republic (2243.66); Stavropolsky Krai (2316.35); Altai Krai (2378.43); Penza } \\
\text { Oblast (2400.67); Republic of Mordovia (2422.79). }\end{array}$ \\
\hline 3018.26 & $\begin{array}{l}\text { Kirov Oblast (2463.93); Kurgan Oblast (2468.26); Pskov Oblast (2472.43); } \\
\text { Chuvash Republic (2533.47); Tambov Oblast (2622.54); Ulyanovsk Oblast } \\
\text { (2713.28); Oryol Oblast (2777.45); Kostroma Oblast (2800.84); Vladimir } \\
\text { Oblast (2838.74); Saratov Oblast (2867.1); Rostov Oblast (2880.74); } \\
\text { Republic of Buryatia (2910.42); Smolensk Oblast (2925.18); Zabaykalsky Krai } \\
\text { (2948.35); Voronezh Oblast (2952.69); Astrakhan Oblast (3012.05). }\end{array}$ \\
\hline $\begin{array}{l}3 \\
3971.9\end{array}$ & $\begin{array}{l}\text { Ryazan Oblast (3043.11); Tula Oblast (3051.29); Tver Oblast (3116.11); } \\
\text { Kursk Oblast (3248.2); Volgograd Oblast (3307.32); Jewish Autonomous } \\
\text { Oblast (3396.85); Republic of Khakassia (3467.37); Kaluga Oblast (3476.59); } \\
\text { Krasnodar Oblast (3649.88); Udmurt Republic (3660.89); Novosibirsk Oblast } \\
\text { (3720.06); Nizhny Novgorod Oblast (3844.74); Yaroslavl Oblast (3925.48); } \\
\text { Omsk Oblast (3959.38); Novgorod Oblast (3960.82). }\end{array}$ \\
\hline $\begin{array}{l}4 \\
5028.07\end{array}$ & $\begin{array}{l}\text { Chelyabinsk Oblast (3974.69); Republic of Bashkortostan (3981.98); } \\
\text { Kaliningrad Oblast (4026.56); Amur Oblast (4037.97); Republic of Karelia } \\
\text { (4071.45); Primorsky Krai (4115.1); Kemerovo Oblast (4288.14); Irkutsk } \\
\text { Oblast (4417.77); Orenburg Oblast (4546.8); Lipetsk Oblast (4570.44); } \\
\text { Belgorod Oblast (4651.31); Samara Oblast (4707.5); Sverdlovsk Oblast } \\
\text { (4832.94); Moscow Oblast (4899.69); Khabarovsk Krai (4916.84); Perm } \\
\text { Oblast (5015.1). }\end{array}$ \\
\hline 5 & $\begin{array}{l}\text { Vologda Oblast (5047.52); Leningrad Oblast (5390.11); Republic of Tatarstan } \\
\text { (5521.62); Tomsk Oblast (5643.53); Arkhangelsk Oblast (5732.84); } \\
\text { Kamchatka Krai (5889.77); Murmansk Oblast (6022.11); St. Petersburg } \\
\text { (6584.55); Krasnoyarsk Oblast (6676.84); Magadan Oblast (7144.47); Komi } \\
\text { Republic (7593.91); Republic of Sakha (Yakutia) (8128.02); Chukotka } \\
\text { Autonomous Region (13909.79); Moscow (14856.61); Sakhalin Oblast } \\
\text { (15603.92); Tyumen Oblast (21717.76). }\end{array}$ \\
\hline
\end{tabular}

Source: own summary based on the data from the Russian Statistical Office website.

The spatial differentiation of per capita GDP in RF regions from 2000 to 2012 can be characterized as follows:

1) The lowest gross per capita GDP not exceeding 2447.47 USD;

Group (1) includes regions with a poorly developed service sector and a high registered unemployment rate (see Table 3);

2) Low value of gross per capita GDP from 2447.47 to 3018.26 USD;

3) Medium value of gross per capita GDP from 3018.26 to 3971.91 USD;

4) High value of gross per capita GDP from 3971.91 to 5028.07 USD;

5) The highest gross value per capita GDP above 5028.07 USD;

Group (5) comprises regions with a well-developed mining and industrial sector. They are also characterized by a low registered unemployment rate (see Table 1).

\subsection{Wages}

Spatial differentiation of wages in the RF regions from 2000 to 2012, broken down into quintile groups, is presented below. 
Table 4: Spatial differentiation of wages in the regions of the Russian Federation between 2000 and 2012

\begin{tabular}{|c|c|}
\hline Group & $\begin{array}{c}\text { RF Region } \\
\text { (Wages) }\end{array}$ \\
\hline 247.59 & $\begin{array}{l}\text { Republic of Dagestan (178.76); Republic of Kalmykia (210.65); } \\
\text { Karachay-Cherkess Republic (213.18); Kabardino-Balkaria (214.68); } \\
\text { Republic of North Ossetia - Alania (216.93); Republic of Mordovia (224.17); } \\
\text { Altai Krai (224.88); Mari El Republic (230.22); Bryansk Oblast (231.78); } \\
\text { Tambov Oblast (233.29); Republic of Ingushetia (233.6); Republic of } \\
\text { Adygea (234.83); Ivanovo Oblast (235.78); Chuvash Republic (240.26); } \\
\text { Ulyanovsk Oblast (245.36); Oryol Oblast (246.15). }\end{array}$ \\
\hline $\begin{array}{l}\mathbf{2} \\
278.26\end{array}$ & $\begin{array}{l}\text { Kirov Oblast (248.57); Kurgan Oblast (250.78); Stavropolsky Krai (254.95); } \\
\text { Kostroma Oblast (255.36); Penza Oblast (256.55); Voronezh Oblast } \\
\text { (259.51); Pskov Oblast (259.67); Kursk Oblast (260.71); Altai Republic } \\
\text { (261.81); Saratov Oblast (262.52); Vladimir Oblast (270.66); Smolensk } \\
\text { Oblast (270.82); Volgograd Oblast (273.78); Udmurt Republic (274.35); } \\
\text { Rostov Oblast (277.24); Orenburg Oblast (278.26). }\end{array}$ \\
\hline $\begin{array}{l}\mathbf{3} \\
325.85\end{array}$ & $\begin{array}{l}\text { Ryazan Oblast (278.31); Tula Oblast (289.78); Astrakhan Oblast (292.18); } \\
\text { Tver Oblast (293.42); Lipetsk Oblast (294.88); Belgorod Oblast (296.56); } \\
\text { Krasnodar Oblast (299.78); Nizhny Novgorod Oblast (300.51); Republic of } \\
\text { Bashkortostan (307.09); Novgorod Oblast (309.48); Yaroslavl Oblast } \\
\text { (310.85); Omsk Oblast (310.87); Tyva Republic (316.61); Kaluga Oblast } \\
\text { (322.5); Samara Oblast (324.46). }\end{array}$ \\
\hline $\begin{array}{l}\mathbf{4} \\
394.58\end{array}$ & 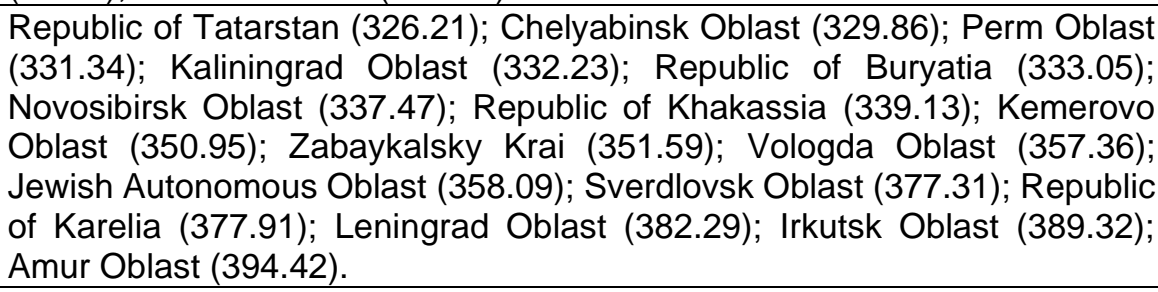 \\
\hline 5 & $\begin{array}{l}\text { Primorsky Krai (394.83); Tomsk Oblast (408.16); Arkhangelsk Oblast } \\
\text { (418.08); Krasnoyarsk Oblast (443.18); Khabarovsk Krai (449.48); Moscow } \\
\text { Oblast (460.91); St. Petersburg (483.92); Komi Republic (498.3); } \\
\text { Murmansk Oblast (547.41); Republic of Sakha (Yakutia) (576.46); } \\
\text { Kamchatka Krai (656.02); Sakhalin Oblast (658.39); Magadan Oblast } \\
\text { (670.24); Moscow (681.81); Tyumen Oblast (785.16); Chukotka } \\
\text { Autonomous Region (918.32). }\end{array}$ \\
\hline
\end{tabular}

Source: own summary based on the data from the Russian Statistical Office website.

When analyzing the data shown in Table 4, one notices that the spatial differentiation of wages in the RF regions from 2000 to 2012 is as follows:

a) The lowest salary not exceeding 247.59 USD;

Group (1) includes regions with a poorly developed mining sector. Most of them are industrial or agricultural;

b) Low salary level from 247.59 to 278.26 USD;

c) Medium salary level from 278.26 to 325.85 USD

d) High salary level from 325.85 to 394.58 USD;

e) The highest salary level above 394.58 USD;

Group (5) comprises regions with well-developed mining and industrial sectors. 


\subsection{Number of $R \& D$ organizations in the region per million inhabitants}

Table 5 lists the quintile groups in terms of the number of R\&D organizations in RF regions between 2000 and 2012.

Table 5: Number of research and development organizations in RF regions in the period between 2000 and 2012 per million inhabitants

\begin{tabular}{|c|c|}
\hline Group & $\begin{array}{c}\text { RF Region } \\
\text { (Number of R\&D Organizations per Million of Inhabitants) }\end{array}$ \\
\hline 13 & $\begin{array}{l}\text { Republic of Ingushetia (5.09); Jewish Autonomous Oblast (7.01); } \\
\text { Stavropolsky Krai (7.46); Orenburg Oblast (8.19); Republic of Khakassia } \\
\text { (8.2); Lipetsk Oblast (9.54); Republic of Dagestan (10.13); Leningrad } \\
\text { Oblast (10.18); Kemerovo Oblast (10.62); Kostroma Oblast (11.06); } \\
\text { Karachay-Cherkess Republic (11.29); Zabaykalsky Krai (11.38); Republic } \\
\text { of Adygea (11.47); Chuvash Republic (11.64); Krasnodar Oblast (11.75). }\end{array}$ \\
\hline 16 & $\begin{array}{l}\text { Mari El Republic (13.02); Chelyabinsk Oblast (13.15); Vologda Oblast } \\
\text { (13.31); Ryazan Oblast (13.89); Altai Krai (14.23); Republic of Mordovia } \\
\text { (14.29); Belgorod Oblast (14.41); Smolensk Oblast (14.74); Kirov Oblast } \\
\text { (14.75); Kurgan Oblast (14.95); Ulyanovsk Oblast (15.08); Tula Oblast } \\
\text { (15.25); Kaliningrad Oblast (15.42). }\end{array}$ \\
\hline 21 & $\begin{array}{l}\text { Pskov Oblast (15.8); Amur Oblast (16.13); Udmurt Republic (16.15); } \\
\text { Republic of Buryatia (16.18); Irkutsk Oblast (16.22); Bryansk Oblast (16.3); } \\
\text { Kabardino-Balkaria (16.4); Republic of Bashkortostan (16.78); Tyumen } \\
\text { Oblast (16.85); Kursk Oblast (16.91); Penza Oblast (17.16); Samara } \\
\text { Oblast (17.68); Novgorod Oblast (17.76); Volgograd Oblast (17.98); } \\
\text { Republic of North Ossetia - Alania (18.54); Perm Oblast (19.38); } \\
\text { Krasnoyarsk Oblast (19.85); Republic of Karelia (20.48). }\end{array}$ \\
\hline 25 & $\begin{array}{l}\text { Vladimir Oblast (20.55); Astrakhan Oblast (20.58); Saratov Oblast (20.92); } \\
\text { Komi Republic (21.07); Omsk Oblast (21.26); Arkhangelsk Oblast (21.3); } \\
\text { Tambov Oblast (21.75); Oryol Oblast (22.16); Primorsky Krai (23.17); } \\
\text { Ivanovo Oblast (23.25); Yaroslavl Oblast (23.26); Republic of Sakha } \\
\text { (Yakutia) (23.84); Rostov Oblast (23.9); Tyva Republic (24.04); Sakhalin } \\
\text { Oblast (24.28); Republic of Tatarstan (24.77). }\end{array}$ \\
\hline 5 & $\begin{array}{l}\text { Voronezh Oblast (25.58); Khabarovsk Krai (25.97); Republic of Kalmykia } \\
\text { (26.42); Sverdlovsk Oblast (26.46); Tver Oblast (27.7); Nizhny Novgorod } \\
\text { Oblast (29.37); Chukotka Autonomous Region (31.03); Murmansk Oblast } \\
\text { (31.25); Altai Republic (35.02); Moscow Oblast (35.78); Kaluga Oblast } \\
\text { (36.65); Kamchatka Krai (41.45); Novosibirsk Oblast (43.99); Magadan } \\
\text { Oblast (44.64); Tomsk Oblast (53.4);Moscow (82); St. Petersburg (84.13). }\end{array}$ \\
\hline
\end{tabular}

Source: own summary based on the data from the Russian Statistical Office website.

Considering the data presented in Table 5, one observes that the number of $R \& D$ organizations in RF regions from 2000 to 2012 is as follows:

1) The smallest number of organizations not exceeding 13;

Group (1) includes agricultural regions with a poorly developed mining industry.

2) Small number of organizations from 13 to 16 ;

3) Medium number of organizations from 16 to 21 ;

4) Large number of organizations from 21 to 25 ;

5) The highest number of organizations above 25;

Group (5) comprises regions with a large number of R\&D organizations. The specific character of these regions is explained by the government's location of industry in the Urals 
and beyond during World War II, and a well-developed mining industry in the regions in question.

\section{Defining a taxonomic index based on Euclidean metrics}

When analyzing the diversification of economic development in RF regions, one should introduce the concepts of a stimulant and a deterrent of economic development. A stimulant of economic development is understood as an economic variable whose high level implies the desired state of the phenomenon under investigation. On the other hand, a deterrent is an economic variable whose high level implies an undesirable state of the studied phenomenon (Majewski, 1999: 10).

Statistical relationship between the stimulant $\left(s_{m k}^{l}\right)$ and deterrent $\left(d_{m k}^{l}\right)$ is expressed in the following transformation:

$$
s_{m k}^{l}=\frac{1}{d_{m k}^{l}}
$$

where:

- indices $l, m$ and $k$ refer to the studied region, period and stimulant/deterrent index respectively.

In order to define a taxonomic index for a region's economic development based on a distance in Euclidean metrics, a standardization process was made using formula (2). The standardization process is based on the following relationship:

$$
\bar{s}_{m k}^{l}=\frac{s_{m k}^{l}}{\max _{l k}\left(s_{m k}^{l}\right)}
$$

where:

$\bar{s}_{m k}^{l}$ - standardized stimulant.

The values $\bar{s}_{m k}^{l}$ belong to the interval $[0,1]$, which enables comparing any values of various standardized stimulants.

In the case where the value of the simulant equals 1 , this can be interpreted as follows: in I region, in $k$ year, variable $m$ assumes the maximum value in the investigated group. This entails the following conclusion: the higher/lower the values adopted by the standardized stimulant $\left(\bar{s}_{m k}^{l}\right)$, the higher/lower the degree of a region's development in terms of the variable described by the stimulant.

These variables comprise four stimulants: investment per capita, GDP per capita, the number of organizations carrying out R\&D per million inhabitants, and wages. In this context, the deterrent is the registered unemployment rate. These variables, however, may not reflect the regional development accurately. In order to obtain a complete picture of regional development, a taxonomic index based on Euclidean metrics must be used. The Euclidean distance indicator enables analyzing independent variables as absolute values. This approach was also used in the analysis of powiat ('district') development in Poland by Tokarski and Jabłoński (2010), Dykas (2010). 
Formula (3) shows the distances of standardized stimulants from 1 for this metric:

$$
W T=\sqrt{\sum_{k=1}^{T} \sum_{m=1}^{n}\left(1-\bar{s}_{m k}^{l}\right)^{2}}
$$

where:

$n$ - number of stimulants used,

$T$ - number of years in the period considered.

This taxonomic index measures the distance between the theoretical pattern that takes the maximum values of variables for each stimulant of $i$ region in $k$ year. It follows that a lower (higher) distance of the indicator is accompanied by a higher (lower) level of development of the region in terms of the variables under consideration. The WT indicator can take values from the interval $\lfloor 0, \sqrt{n T}]$, where $n$ is the number of stimulants analyzed.

\section{Differentiation in the development of the Russian Federation's regions based on Euclidean distance index}

The analysis covers 79 regions of the RF in the period between 2000 and 2012. The data was taken from the website run by the Russian Statistical Office. Drawing on the data collected, index values for these regions were calculated.

Table 6 presents the classification of RF regions in terms of the level of economic development measured by the taxonomic index, divided into quintile groups.

Table 6: Classification of RF regions based on to values of the taxonomic index in the years 2000-2012

\begin{tabular}{|c|c|}
\hline Group & $\begin{array}{c}\text { RF Region } \\
\text { (Taxonomic Index) }\end{array}$ \\
\hline 6.804 & $\begin{array}{l}\text { Moscow (5.082); Chukotka Autonomous Region (5.705); Tyumen Oblast } \\
\text { (5.713); St. Petersburg (5.846); Sakhalin Oblast (5.951); Magadan Oblast } \\
\text { (6.271); Republic of Sakha (Yakutia) (6.458); Kamchatka Krai (6.461); Tomsk } \\
\text { Oblast (6.5); Moscow Oblast (6.502); Komi Republic (6.641); Murmansk } \\
\text { Oblast (6.682); Khabarovsk Krai (6.761); Arkhangelsk Oblast (6.779); Kaluga } \\
\text { Oblast (6.798); Novosibirsk Oblast (6.803). }\end{array}$ \\
\hline 7.069 & $\begin{array}{l}\text { Republic of Tatarstan (6.805); Krasnoyarsk Oblast (6.806); Sverdlovsk Oblast } \\
\text { (6.867); Leningrad Oblast (6.883); Nizhny Novgorod Oblast (6.914); Yaroslavl } \\
\text { oblast (6.923); Primorsky Krai (6.941); Tver Oblast (6.964); Samara Oblast } \\
\text { (6.976); Vologda Oblast (6.982); Amur Oblast (6.987); Perm Oblast (7.016); } \\
\text { Republic of Karelia (7.025); Novgorod Oblast (7.032); Belgorod Oblast } \\
\text { (7.034); Lipetsk Oblast (7.068). }\end{array}$ \\
\hline 7.192 & $\begin{array}{l}\text { Voronezh Oblast (7.077); Kaliningrad Oblast (7.078); Altai Republic (7.083); } \\
\text { Irkutsk Oblast (7.089); Omsk Oblast (7.103); Chelyabinsk Oblast (7.107); Tula } \\
\text { Oblast (7.117); Astrakhan Oblast (7.118); Republic of Bashkortostan (7.127); } \\
\text { Krasnodar Oblast (7.128); Rostov Oblast (7.134); Oryol Oblast (7.16); } \\
\text { Kemerovo Oblast (7.161); Vladimir Oblast (7.184); Saratov Oblast (7.189). }\end{array}$ \\
\hline $\begin{array}{l}4 \\
7.283\end{array}$ & $\begin{array}{l}\text { Tambov Oblast (7.193); Ivanovo Oblast (7.195); Kursk Oblast (7.196); } \\
\text { Volgograd Oblast (7.205); Udmurt Republic (7.206); Ryazan Oblast (7.211); } \\
\text { Jewish Autonomous Oblast (7.219); Republic of Mordovia (7.231); Penza } \\
\text { Oblast (7.24); Smolensk Oblast (7.251); Orenburg Oblast (7.257); Ulyanovsk } \\
\text { Oblast (7.261); Republic of Buryatia (7.269); Kostroma Oblast (7.275); } \\
\text { Republic of Khakassia (7.281); Zabaykalsky Krai (7.282). }\end{array}$ \\
\hline
\end{tabular}


Pskov Oblast (7.285); Tyva Republic (7.29); Republic of Kalmykia (7.291); Kirov Oblast (7.308); Bryansk Oblast (7.319); Kurgan Oblast (7.349); Republic of North Ossetia - Alania (7.358); Chuvash Republic (7.358); Altai Krai (7.373); Mari El Republic (7.39); Stavropolsky Krai (7.42); Republic of Adygea (7.437); Kabardino-Balkaria (7.447); Karachay-Cherkess Republic (7.497); Republic of Dagestan (7.544); Republic of Ingushetia (7.693).

Source: own summary based on the data from the Russian Statistical Office website.

Analyzing the data from Table 6 , the resulting spatial differentiation in terms of the taxonomic index value is as follows:

a) The most developed regions where the index value does not exceed 6.804;

Group (1) includes regions with the best-developed mining industry or service sector;

b) Highly developed regions where the index value ranges from 6.804 to 7.069 ;

c) Medium-developed regions where the index value ranges from 7.069 to 7.192 ;

d) Poorly developed regions where the index value ranges from 7.192 to 7.283;

e) The worst-developed regions where the index value exceeds 7.283;

Group (5) includes regions with a poorly developed mining or processing industry or a poorly developed service sector. They are mostly agricultural regions.

\section{Preliminary analysis of convergence/divergence}

This part of the study provides a comparison of the spatial differentiation of the macroeconomic variables discussed and a preliminary analysis of convergence/divergence processes.

Table 7: Selected spatial differentiation indices of the investigated macroeconomic variables

\begin{tabular}{|c|c|c|c|c|c|}
\hline \multirow{2}{*}{ Diff. index } & \multicolumn{5}{|l|}{ Variable } \\
\hline & $\begin{array}{l}\text { Unemployment } \\
\text { rate }\end{array}$ & $\begin{array}{l}\text { Investment } \\
\text { per capita }\end{array}$ & $\begin{array}{l}\text { GDP per } \\
\text { capita }\end{array}$ & Wages & $\begin{array}{l}\text { Number of } \\
R \& D \text { org. }\end{array}$ \\
\hline Max/Min & 38.31 & 45.23 & 26.55 & 5.99 & 29.28 \\
\hline$V_{S}$ & 0.40 & 1.07 & 0.78 & 0.43 & 0.66 \\
\hline$V_{d}$ & 0.34 & 0.56 & 0.45 & 0.30 & 0.42 \\
\hline$V_{Q}$ & 0.40 & 0.78 & 0.65 & 0.42 & 0.59 \\
\hline
\end{tabular}

$\mathrm{V}_{\mathrm{s}}$ - coefficient of variation based on standard deviation; $\mathrm{V}_{\mathrm{d}}$ - coefficient of variation based on average deviation; $V_{Q}$ - coefficient of variation based on quadrant deviation; GDP - gross domestic product; R\&D - research and development.

Source: own calculations based on the data from the Russian Statistical Office website.

In this part of the paper, an analysis of convergence/divergence processes is presented. For this purpose, these processes need to be defined first (Malaga, Kliber, 2007).

In the light of macroeconomics, the concept of convergence refers to the process of levelling up the values of the main macroeconomic variables across countries or regions with different variable output values. Performing a convergence analysis can provide an answer to the question whether regions (countries) with significantly different output levels of certain variables will approach each other in magnitude or grow further away from each other. Making up the distance to the most developed economies (regions) is the process of real convergence, while growing apart of a poorer economy (region) from better developed economies (regions) is called the process of divergence.

Two technical dimensions of convergence can be found in the literature: $\sigma$-convergence and $\beta$-convergence. $\sigma$-convergence occurs when the dispersion of a macroeconomic variable between regions or countries decreases over time, while $\beta$-convergence occurs when there 
is a decreasing dependence between the achieved rate of economic growth and the initial level of the investigated macroeconomic variable. It should be mentioned that, apart from $\sigma$-convergence and $\beta$-convergence, other types of convergence are discussed in the literature, for example, conditional convergence, unconditional conditional and club convergence.

In general, $\sigma$-convergence is measured by changes in the standard deviation of the variable under investigation. If the standard deviation increases (decreases) with time, then it is said to be the process $\sigma$-convergence ( $\sigma$-divergence).

In the latter part of this paper, the process $\sigma$-convergence will be tested not by changes in the standard deviation, which is an absolute measure of dispersion of a variable, but by changes in the coefficients of variation $V_{S}, V_{d}$ and $V_{Q}$, which are relative measures of dispersion. Figures 1-3 show the individual coefficients of variation.

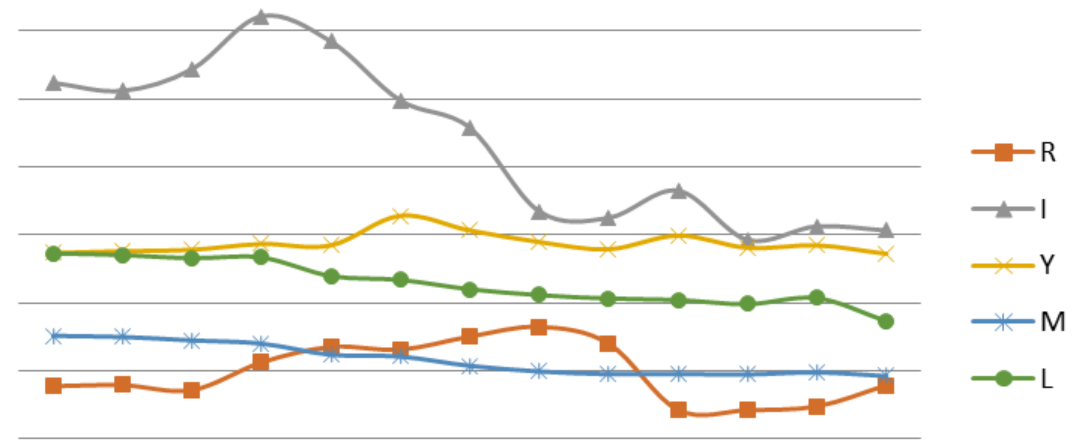

Figure 1: Coefficients of variation $V_{S}$ of the investigated macroeconomic variables for the period between 2000 and 2012

$R$ - unemployment rate; I - investment per capita; $Y$ - GDP per capita; $M$ - wages; $L$ - number of R\&D organizations

Source: own study based on the data from the Russian Statistical Office website.

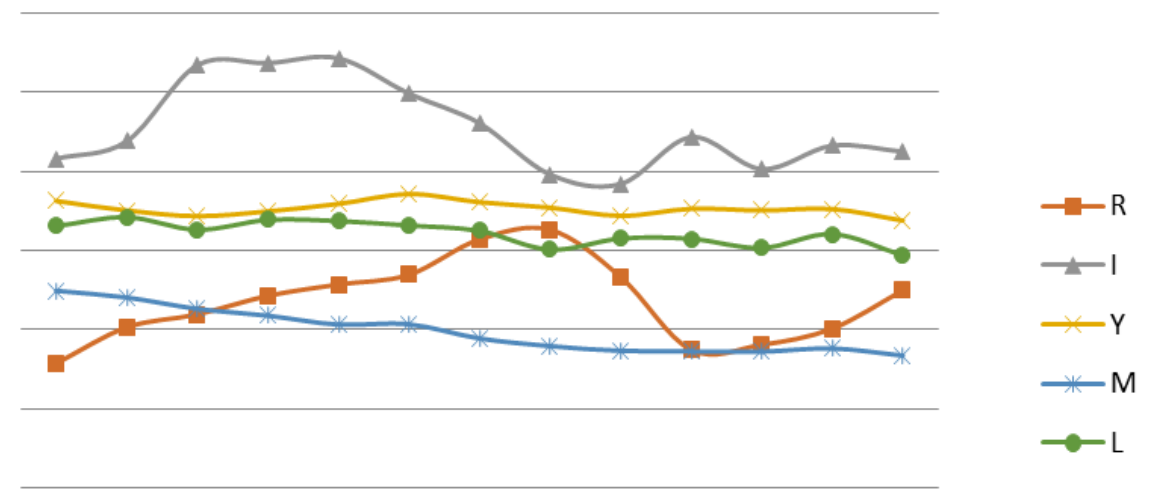

Figure 2: Coefficients of variation $\mathrm{V}_{d}$ of the investigated macroeconomic variables for the period between 2000 and 2012

$R$ - unemployment rate; I - per capita investments; $Y$ - GDP per capita; $M$ - wages; $L$ - number of $R$ \& D organizations

Source: own study based on the data from the Russian Statistical Office website. 


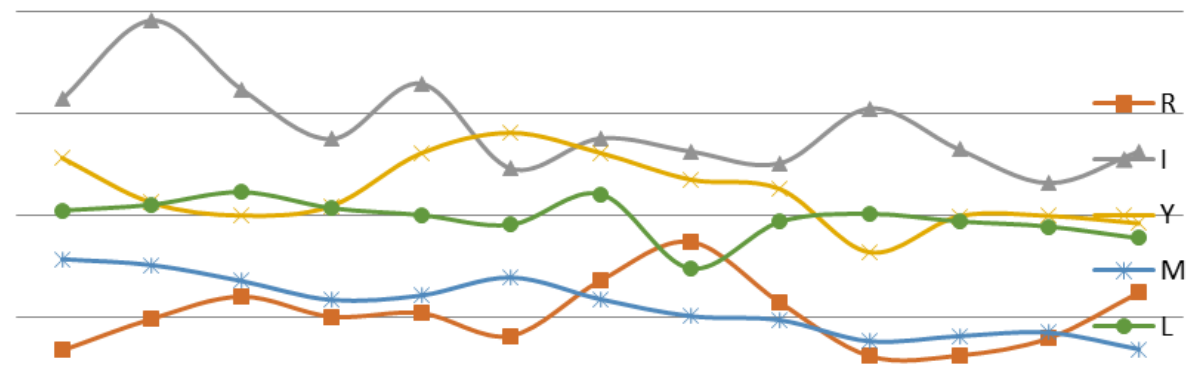

Figure 3: Coefficients of variation $\mathrm{V}_{\mathrm{Q}}$ of the investigated macroeconomic variables for the period between 2000 and 2012

$\mathrm{R}$ - unemployment rate; I - per capita investments; $Y$ - GDP per capita; $M$ - wages; $L$ - number of R \& D organizations

Source: own study based on the data from the Russian Statistical Office website.

Figures 1-3 illustrate that the process of spatial $\sigma$-convergence in the regions of the Russian Federation concerned the following macroeconomic indicators:

- $\quad$ GDP per capita: $V_{S}$ fell from about 0.75 in 2000 to 0.74 in $2012, V_{d}$ from 0.46 to 0.44 , and $V_{Q}$ from 0.71 to 0.58 .

- Wages: coefficient of variation $V_{S}$ dropped from about 0.50 in 2000 to 0.39 in 2012, $V_{d}$ from 0.35 to 0.27 , and $V_{Q}$ from 0.51 to 0.34 ;

- Number of R\&D organizations per million inhabitants: coefficient of variation $V_{S}$ dropped from about 0.75 in 2000 to 0.55 in 2012, $V_{d}$ from 0.43 to 0.39 , and $V_{Q}$ from 0.61 to 0.55 .

The convergence process did not concern the spatial differentiation of per capita investment, as the investigated coefficients of variation increased in some years and decreased in others. On the other hand, there was $\sigma$-divergence process in the case of the registered unemployment rate. The coefficients of variation for this macroeconomic variable varied from 0.35 in 2000 to 0.36 in $2012\left(V_{S}\right)$, from 0.26 to $0.35\left(V_{d}\right)$, and from 0.33 to $0.45\left(V_{Q}\right)$.

\section{In conclusion}

This paper gives a $\sigma$-convergence/divergence analysis and a statistical analysis regarding the level of development of RF regions in the period from 2000 to 2012 . The regions were compared in terms of: registered unemployment rates, per capita investment, per capita GDP, wages, and the number of R\&D organizations per million inhabitants. The level of economic development in the RF can be linked to the structure of the individual region's economy. The mining industry, processing of crude oil and natural gas, as well as research and development work are conducive to growth in investment, while the well-developed service sector is conducive to growth in wages and employment (Russian Institute of Spatial Planning, 2020).

The level of development was also considered by means of the taxonomic index. The following conclusions can be drawn from the study. The most developed RF regions include: Moscow (5.082), Chukotka Autonomous Region (5.705), Tyumen Oblast (5.713) and St. Petersburg (5.846). The high level of economic development in Moscow and St. Petersburg, are explained by the good condition of the service sector and the development of industry branches specific to Moscow, St. Petersburg and their immediate environment, such as mechanical engineering, food industry, oil and gas processing, research and development, pharmaceutical industry, metallurgy, chemical industry, and production of building materials. In addition, the hospitality sector is also well-developed in 
Saint Petersburg. Industry in these regions is labour-intensive. The high level of industrial development is accompanied by an increase in GDP, wages and employment.

In the case of the Chukotka Autonomous Okrug, with a small number of residents, there is a well-developed oil and gas industry and mining industry (extraction of non-ferrous metals). The small number of residents and relatively large capital expenditures in the mining industry had a positive impact on the region's ranking among the most developed RF regions.

The high level of development in the Tyumen Region is due to the administrative affiliation to the last Khanty-Mansi Autonomous District and to the Yamal-Nenets Autonomous district. Khanty-Mansiysk Autonomous Okrug is characterized by a well-developed oil and natural gas industry, power industry, oil and gas processing, food industry, research and development, and pharmaceutical industry. It is worth noting that the Khanty-Mansiysk Autonomous Okrug has the largest share in oil and gas production in Russia. Yamal-Nenets Autonomous Okrug has a well-developed oil and natural gas industry. These industry features in the Tyumen Oblast, coupled with investment in research and development, determine the region's position in the ranking. The mining industry in the Tyumen Oblast attracts investment related to the production of natural gas and oil, resulting in an increase in employment, wages and fixed assets.

The worst developed regions are the southern Caucasian regions: Republic of Ingushetia (7.693), Republic of Dagestan (7.544), Karachay-Cherkess Republic (7.497), Kabardino-Balkaria (7.447).

In these regions, the industry and the tertiary sector are underdeveloped. Most of the Caucasian regions are also agricultural areas. In the North Caucasian zone there are terrorist threats, economic insecurity and criminalization of Caucasian regions' economy, which affects their investment appeal. The political outlook is instable, so there are no government subsidies.

It should be noted that not all the data of the Russian Statistical Office reflects the actual state of affairs concerning the processes taking place in the Russian economy. The data concerning unemployment (high level of hidden unemployment) and wages (grey zone/ unrecorded wages) is not entirely reliable.

The registered unemployment rate in most regions of the Russian Federation is also much smaller than the actual one. This can be explained by the lack of interest in registering unemployed individuals owing to inadequate management policies in Russian employment offices and to minimal support for the unemployed from the Russian government (with the exception of North Caucasian republics, where support for the unemployed is much higher than in other RF regions). This is corroborated by the registered unemployment rate in the Republic of Ingushetia, which is much closer to the actual one compared to the rest of $\mathrm{RF}$ regions.

\section{References}

Barro, R. J., Sala-i-Martin, X., 2004. Economic Growth. Cambridge, Massachusetts, London, England: The MIT Press.

Blackwelder, A. R., 1966. Taxonomy. A Text and Reference Book, New York: Wiley. Cole, A. J., 1968. Numerical Taxonomy. New York: Academic Press.

Dykas, P., 2010. Taksonomiczne wskaźniki przestrzennego zróżnicowania rozwoju powiatów województwa podkarpackiego [Taxonomic indices of spatial differentiation in the development of the districts of Podkaprackie Province]. Studia-Prawno Ekonomiczne, LXXX, pp. 91-116.

Gajewski, P., Tokarski, T., 2004. Czy w Polsce występuje efekt konwergencji regionalnej? [Is there regional convergence in Poland?]. Studia Ekonomiczne, 1-2/XL-XLI, pp. 45-70. Islam, N., 2003. What Have We Learnt from the Convergence Debate? Journal of Economic Surveys, 17(3), pp. 309-362. 
Kornowski, A., 2015. Zróżnicowanie zmiennych makroekonomicznych oraz rozwoju regionów części azjatyckiej Federacji Rosyjskiej [Differentiation of macroeconomic variables and development in the regions of the Asian part of the Russian Federation]. Humanities and Social Sciences, XX (22), pp. 55-77

Majewski, S., 1999. Szeregowanie krajów przy pomocy Diagramu Czekanowskiego $i$ Taksonomicznego Miernika Rozwoju [Ranking of countries based on the Czekanowski Diagram and Taxonomic Development Metric]. Wiadomości Statatystyczne, 8, pp. 76-84.

Malaga, K., Kliber, P., 2007. Konwergencja a nierówności regionalne w Polsce w świetle neoklasycznych modeli wzrostu [Convergence and regional inequalities in Poland in the light of neoclassical models of development]. Poznan, Wydawnictwo Akademii Ekonomicznej w Poznaniu.

Mezzich, J. E., Solomon, H., 1980. Taxonomy and Behavioral Science. New York: Academic Press.

Misiak, T., Tokarski, T., Włodarczyk, R.W., 2011. Konwergencja czy dywergencja polskich rynków pracy [Convergence or divergence of Polish labour markets]. „Gospodarka Narodowa" 7-8, pp. 47-69.

Russian Institute of Spatial Planning (Институт территориального планирования), Available at www.urbanica.spb.ru. [Accessed 03.03.2020].

Russian Statistical Office (Федеральная служба государственной статистики - Росстат), Available at www.gks.ru. [Accessed 03.03.2020].

Sneath, P. H. A., Sokal, R. R., 1973. Numerical Taxonomy. San Francisco: W. H. Freeman. Taylor, P. J., 1970. Quantitative methods in regional taxonomy. Progress in Geography, 2, pp.3-64.

Tokarski, T., Jabłoński, Ł., 2010. Taksonomiczne wskaźniki przestrzennego zróżnicowania rozwoju powiatów [Taxonomic indices of spatial differentiation in district development]. Studia-Prawno Ekonomiczne, LXXXI, pp. 261-289.

\section{Bio-note}

Aleksy Kornowski is $\mathrm{PhD}$ of the Faculty of Management and Social Communication at the Jagiellonian University, Cracow, Poland. Main research interests: regional economic development, HRM, cross cultural management. 